\title{
Immunohistochemical Localization of Ciliary Neurotrophic Factor Receptor $\alpha$ Expression in the Rat Nervous System
}

\author{
A. John MacLennan, Emily N. Vinson, Lianne Marks, Diana L. McLaurin, Marylynn Pfeifer, and Nancy Lee \\ Department of Neuroscience, University of Florida Brain Institute, University of Florida College of Medicine, \\ Gainesville, Florida 32610-0244
}

Ciliary neurotrophic factor receptor $\alpha$ (CNTFR $\alpha)$ is essential for normal embryonic development and may be involved in postnatal and adult neuronal maintenance. In addition, a rapidly growing body of evidence suggests that CNTFR $\alpha$ serves as a site of action for future growth factor therapeutics capable of treating a wide variety of disorders resulting from neuronal loss. We raised two polyclonal, anti-CNTFR $\alpha$ antisera against synthetic peptides corresponding to independent regions of rat CNTFR $\alpha$. Western blot and immunohistochemical analyses indicated that affinity-purified preparations of both antisera specifically recognize CNTFR $\alpha$. In the adult brain, the highest levels of CNTFR $\alpha$ immunoreactivity were found in the perikarya, dendrites and, occasionally, the axons of several distinct classes of

The in vitro and in vivo actions of ciliary neurotrophic factor (CNTF) suggest that endogenous CNTF plays a role in nervous system development and maintenance and that exogenously administered CNTF may be able to clinically reduce neuronal loss resulting from a wide variety of traumatic and genetic lesions. Thus, CNTF influences the in vitro survival, proliferation, and differentiation of many cell types (for review, see Ip and Yancopoulos, 1992; Richardson, 1994). In vivo, CNTF induces motor neuron sprouting (Gurney et al., 1992), reduces the naturally occurring, developmentally associated death of spinal motor neurons (Oppenheim et al., 1991), reduces the death of intermediolateral column spinal cord neurons after adrenal medulla removal (Blottner et al., 1989), decreases muscle atrophy and potentiates nerve regeneration after peripheral ncrve lcsion (Hclgren et al., 1992; Sahenk et al., 1994), and decreases the axotomy-induced death of neurons in the facial nucleus [Sendtner et al., 1990 (but see also Clatterbuck et al., 1994)], thalamus (Clatterbuck et al., 1993), medial septum (Hagg et al., 1992), substantia nigra (Hagg and Varon, 1993), and retina (Mey and Thanos, 1993). In addition, CNTF administration has been shown to slow the development of behavioral and anatomical defects associated with three genetic mouse models of human motor neuron disease (Helgren et al., 1992; Sendtner et al., 1992; Mitsumoto et al., 1994a) and arrest the development of these symptoms in one model when coadministered with brain-derived neurotrophic factor (BDNF) (Mitsumoto et al., 1994b).

\footnotetext{
Reccived July 28, 1995; revised Oct. 4, 1995; accepted Oct. 11, 1995.

This research was supported by Grant DA07244 to A.J.M. from the National Institute on Drug Abuse. We thank Drs. Kevin Anderson, Alfred Chung, Marieta Heaton, Brian Hollander, Richard Johnson, and David Muir for valuable discussions.

Correspondence should be addressed to A. John MacLennan, Department of Neuroscience, P.O. Box 100244, University of Florida Health Science Center, Gainesville, FL 32610-0244.

Copyright (C) 1996 Society for Neuroscience $0270-6474 / 96 / 160621-10 \$ 05.00 / 0$
}

neurons including hippocampal formation neurons, some sensory neurons, and many neurons involved in motor control. CNTFR $\alpha$ immunoreactivity also was concentrated in the following: perikarya, dendrites, and axons of ventral horn motor neurons in adult spinal cord; perikarya and axons of adult dorsal root ganglion neurons; and axons in adult peripheral nerve. In embryonic tissue, the highest levels of CNTFR $\alpha$ immunoreactivity were observed in differentiating neurons and their processes. Therefore, the present data suggest that CNTFR $\alpha$ serves several diverse functions in adulthood and during development.

Key words: CNTF; CNTF receptor $\alpha$; development; embryonic; immunohistochemistry; antibody

Evidence from molecular cloning, heterologous expression, and cross-linking studies indicates that CNTF produces most, and possibly all, of its effects by binding to a protein referred to as CNTF receptor $\alpha$ (CNTFR $\alpha$ ) (Davis et al., 1991, 1993a,b; Ip et al., 1992, 1993; Baumann et al., 1993; Huber et al., 1993). The CNTF-CNTFR $\alpha$ complex, in combination with two transmembrane proteins [leukemia-inhibitory growth factor receptor $\beta$ $(\mathrm{LIFR} \beta)$ and gp130] and associated Janus kinases, initiates a series of intracellular tyrosine phosphorylations that ultimately lead to changes in gene expression (Ip et al., 1992, 1993; Bonni et al., 1993; Davis et al., 1993b; Stahl et al., 1993, 1995; Boulton et al., 1994; Stahl and Yancopoulos, 1994).

Recent research indicates that CNTFR $\alpha$ plays an essential role in development in that genetic disruption ("knock-out") of the CNTFR $\alpha$ gene in mice leads to death shortly after birth accompanied by a variety of developmental defects (Stahl and Yancopoulos, 1994). Given that CNTF is expressed at very low levels during embryonic development (Sendtner et al., 1994) and knockout of the CNTF gene does not affect embryonic development noticeably (Masu et al., 1993), the CNTFR $\alpha$ knock-out data strongly suggest that an as yét unidentified CNTF-like ligand(s) activates CNTFR $\alpha$ during this stage of ontogeny.

Northern blot studies have shown that CNTFR $\alpha$ mRNA is restricted primarily to neuronal cell lines and nervous system tissues from the early stages of nervous system development to adulthood (Davis et al., 1991; Ip et al., 1993; MacLennan et al., 1994). An in situ hybridization study has demonstrated that CNTFR $\alpha$ mRNA is found in neurons in many regions of the developing and adult nervous systems, with some regions and cell types displaying relatively elevated levels of expression (Ip et al., 1993). The expression of CNTFR $\alpha$ protein in the nervous system has been examined in a Western blot experiment that detected CNTFR $\alpha$ in some regions of the adult and postnatal brain (Kirsch 
and Hofmann, 1994). However, despite the essential role of CNTFR $\alpha$ in development and its potential as a pharmacological site of action for therapeutics, the current literature provides no information regarding the cellular and subcellular pattern of in vivo CNTFR $\alpha$ expression.

This report describes the generation and characterization of anti-CNTFR $\alpha$ antisera and the immunohistochemical localization of CNTFR $\alpha$ in the adult and embryonic nervous systems.

\section{MATERIALS AND METHODS}

Antibody production. Three peptides (peptide 1, $\mathrm{NH}_{2}$-TQKHSPQEAPHVQYER-COOH; peptide 2, $\mathrm{NH}_{2}$-RRLEVTWQTPSTWPDPFS-COOH; peptide $3, \mathrm{NH}_{2}$-WTEWPRHLTTEAQAPE-COOH) corresponding to potentially antigenic and exposed regions of rat CNTFR $\alpha$ that are not homologous to any other known proteins, with the exception of human CNTFR $\alpha$, were conjugated individually to keyhole limpet hemocyanin by incubation in $12.5 \%$ glutaraldehyde for $1 \mathrm{hr}$ at room temperature. Conjugates were extensively dialyzed against PBS ( $7 \mathrm{~mm} \mathrm{Na}_{2} \mathrm{HPO}_{4}, 3 \mathrm{~mm} \mathrm{NaH}_{2} \mathrm{PO}_{4}$, and 130 $\mathrm{mm} \mathrm{NaCl}$ ) and emulsified with Freund's adjuvant before injection into female New Zealand White rabbits (three rabbits/conjugate). Subcutaneous injections of $\sim 0.5 \mu \mathrm{mol}$ of conjugated peptide were performed on a biweekly schedule. The first injection contained complete adjuvant, whereas all subsequent injections contained incomplete adjuvant. Serum samples were collected $10 \mathrm{~d}$ after each injection, and antibody production was evaluated by ELISA. Antisera were affinity-purified with Sepharose-4B columns containing the corresponding antigen peptides conjugated to ovalbumin. Rriefly, antisera were diluted in PBS and loaded on the columns, which then were extensively washed ( 15 column volumes) with PBS. Purified antisera were cluted in fractions with $0.1 \mathrm{M}$ glycine, $\mathrm{pH} 2.5$, immediately neutralized with $1.0 \mathrm{M}$ Tris, $\mathrm{pH} 8.0$, dialyzed against PBS, and stored at $-80^{\circ} \mathrm{C}$ with the addition of $2.5 \mathrm{~mm}$ sodium azide. ELISA analysis of the purified antisera demonstrated that in each case the antisera recognized the appropriate peptide but did not recognize ovalbumin. The purified antisera were used in immunohistochemistry and Western blot experiments at concentrations corresponding to 1:500-1:1000 dilutions of the unpurified antisera.

Western blot analysis. Rat C6 glioma cells were cultured in Dulbecco's modified Eagle's medium containing $10 \%$ fetal bovine serum (FBS). Rat PC12 pheochromocytoma cells were cultured in RPMI 1640 media with $10 \%$ horse serum and $5 \%$ FBS according to standard procedures (Greene et al., 1991). Cells at 50-80\% confluence were rinsed three times (while anchored to plates) with serum-free media, incubated at $37^{\circ} \mathrm{C}$ in OptiMEM I media (Bethesda Research Labs, Bethesda, MD) for $3 \mathrm{hr}$, homogenized in SDS buffer ( $70 \mathrm{~mm}$ Tris, $0.5 \mathrm{~mm}$ ethylenediaminetetraacetate, $80 \mathrm{~mm}$ SDS, $1.0 \mathrm{~mm}$ phenylmethyl sulfonyl fluoride, $10 \mu \mathrm{g} / \mathrm{ml}$ aprotinin, and $10 \mu \mathrm{g} / \mathrm{ml}$ leupeptin), $\mathrm{pH} 6.8$, incubated with agitation at $4^{\circ} \mathrm{C}$ for $30 \mathrm{~min}$, and spun at $150,000 \times \mathrm{g}$ for $15 \mathrm{~min}$. Tissue harvested from adult brain regions was homogenized immediately in the SDS buffer, incubated with agitation at $4^{\circ} \mathrm{C}$ for $2 \mathrm{hr}$, and spun at $150,000 \times \mathrm{g}$ for 30 min. Solubilized proteins $(-10 \mu \mathrm{g}$ of protein/lane) were boiled for $3 \mathrm{~min}$ in SDS loading buffer, iced, separated on a $4-15 \%$ gradient polyacrylamide gel, and transferred to nitrocellulose membranes. The membranes were Ponceau-stained afterward to confirm equal loading and transfer of proteins. After destaining, the membranes were incubated for 1 hr in blocking buffer $(20 \mathrm{~mm}$ Tris, $150 \mathrm{mM} \mathrm{NaCl}, 0.1 \%$ Tween 20 , and $5 \%$ powdered nonfat milk), $\mathrm{pH} 7.4$, followed by a $1 \mathrm{hr}$ incubation in the same solution with affinity-purified anti-CNTFR $\alpha$ antiserum. The blots then were washed three times ( $10 \mathrm{~min}$ each time) in blocking buffer, incubated for $1 \mathrm{hr}$ in a 1:2000 dilution of secondary antibody (ECL kit, Amersham, Arlington Heights, IL) in blocking buffer, washed for $10 \mathrm{~min}$ in blocking buffer, washed five times ( 5 min each time) in $20 \mathrm{~mm}$ Tris, $150 \mathrm{~mm} \mathrm{NaCl}$, $\mathrm{pH} 7.4$ and, finally, processed with enhanced chemiluminescence reagents according to the manufacturer's instructions and exposed to film.

Immunohistochemistry. Long-Evans embryonic day 13 (E13), E14, E16, and E18 rat embryos (E1, day after insemination) were fixed in $4 \%$ $p$-formaldehyde $/ 0.1 \mathrm{M}$ phosphate buffer, $\mathrm{pH} 7.2$, for various lengths of time from $2 \mathrm{hr}$ to overnight at $4^{\circ} \mathrm{C}$ and transferred to $15 \%$ sucrose $/ 0.1 \mathrm{M}$ phosphate buffer, $\mathrm{pH} 7.2$, containing $2.5 \mathrm{~mm}$ sodium azide for at least 24 hr at $4^{\circ} \mathrm{C}$ before sectioning. Adult tissues were removed from IongEvans male rats after perfusion with $4 \%$-formaldehyde $/ 0.1 \mathrm{~m}$ phosphate buffer, $\mathrm{pH} 7.2$, and incubated at $4^{\circ} \mathrm{C}$ in the sucrose solution for at least 24 hr before sectioning.

Thirty micron free-floating sections of the embryos and brains were incubated sequentially at room temperature in $0.3 \% \mathrm{H}_{2} \mathrm{O}_{2}$ in methanol for
$30 \mathrm{~min}$, in PBS, $\mathrm{pH} 7.2$, for $30 \mathrm{~min}$, in PBS containing $0.4 \%$ Triton $\mathrm{X}-100$ for $30 \mathrm{~min}$, in PBS for $15 \mathrm{~min}$, and in blocking solution [PBS, $0.3 \%$ Triton $\mathrm{X}-100$, $0.03 \%$ bovine serum albumin (BSA), $10 \%$ normal goat serum] for $1 \mathrm{hr}$. The sections were incubated subsequently for $3 \mathrm{~d}$ at $4^{\circ} \mathrm{C}$ in PBS, $0.3 \%$ Triton $\mathrm{X}-100,0.03 \%$ BSA, $2 \%$ normal goat serum, and affinity-purified anti$\mathrm{CNTFR} \alpha$ antisera. They then were incubated sequentially at room temperature in the following: PBS twice $(30 \mathrm{~min}$ each time); PBS containing biotinylated secondary antibody, $0.3 \%$ Triton X-100, $0.03 \%$ BSA, and $2 \%$ normal goat serum for $1 \mathrm{hr}$; and PBS twice ( 30 min each time) before staining with the avidin-biotin-peroxidase method (ABC elite kit, Vector Laboratories, Burlingame, $\mathrm{CA}$ ) using 3,3'-diaminobenzidine as a substrate and nickel ammonium sulfate as an enhancer. All observations are based on examination of tissue from at least three rats.

\section{RESULTS}

\section{Production, purification, and characterization of antisera that recognize CNTFR $\alpha$ in tissue sections}

Nine rabbits were injected on a biweekly schedule with one of three 16-18 mer synthetic peptides corresponding to nonoverlapping segments of rat CNTFR $\alpha$ (see Materials and Methods). ELISA analyses of resulting antisera indicated that antibody titers increased progressively such that all antisera harvested after injection 6 and later recognized appropriate antigen peptides at maximum antisera dilutions ranging from $1: 15,000$ to $1: 50,000$. After purification by affinity chromatography on columns containing antigen peptide, the antisera were screened immunohistochemically to determine whether any contained antibodies that potentially recognize CNTFR $\alpha$ in tissue sections. These initial experiments were conducted with sections of E14 rat embryos and adult rat brains. The results indicated that one of the antisera raised against peptide 1 (antiserum " $1 \mathrm{Y}^{\text {") }}$ ) and one of the antisera raised against peptide 3 (antiserum " $3 X^{\prime}$ ) produced cellular labeling consistent with reported CNIFR $\alpha$ Northern and in situ hybridization data as well as with the effects of CNTF in vitro and in vivo (Davis et al., 1991; Ip et al., 1993; MacLennan et al., 1994; Richardson, 1994). No labeling was detected when the primary antibodies were omitted from the procedure.

Western blot studies with the $1 \mathrm{Y}$ and $3 \mathrm{X}$ antisera indicated that both antisera selectively recognize a protein species that migrates with an apparent molecular weight of $78 \mathrm{kDa}$ (Fig. 1), although $3 \mathrm{X}$ is significantly more effective than $1 \mathrm{Y}$. The size of the recognized protein is consistent with a selective detection of CNTFR $\alpha$ by both antisera given that cross-linking studies estimate CNTFR $\alpha$ to be $\sim 80$ kDa (Huber et al., 1993; Stahl et al., 1993). Furthermore, the antisera detect the $\sim 78 \mathrm{kDa}$ protein in adult brain regions and rat PC12 pheochromocytoma cells, both of which express CNTFR $\alpha$ mRNA (Davis et al., 1991; Ip et al., 1993; MacLennan et al., 1994) but do not detect the $\sim 78 \mathrm{kDa}$ protein in rat $\mathrm{C} 6$ glioma cells, which do not express (N'IFK $\alpha$ mRNA (MacLennan et al., 1994). In addition, the $\sim 78 \mathrm{kDa}$ band was absent when primary antibody was preincubated with antigen peptide and when blots were probed without primary antibody or with preimmune sera (data not shown). The antibodies also detected minor species between 66 and $45 \mathrm{kDa}$ in PC12 cell lysates. We suspect that these species are proteolytic degradation products of CNTFR $\alpha$, because the labeling is similarly blocked by antigen preincubation of primary antibody, is dependent on primary antibody, and is absent in preimmune sera controls (data not shown).

Our subsequent immunohistochemical studies with the $3 \mathrm{X}$ and $1 \mathrm{Y}$ antisera (see below) produced two key results indicating that the antisera recognize CNTFR $\alpha$ in tissue sections. First, the antisera, raised against two independent sequences of CNTFR $\alpha$, labeled the same cells and subcellular regions although, in a manner similar to their actions in Western blot experiments, $3 \mathrm{X}$ generally produced a more intense signal than $1 Y$. Second, pre- 


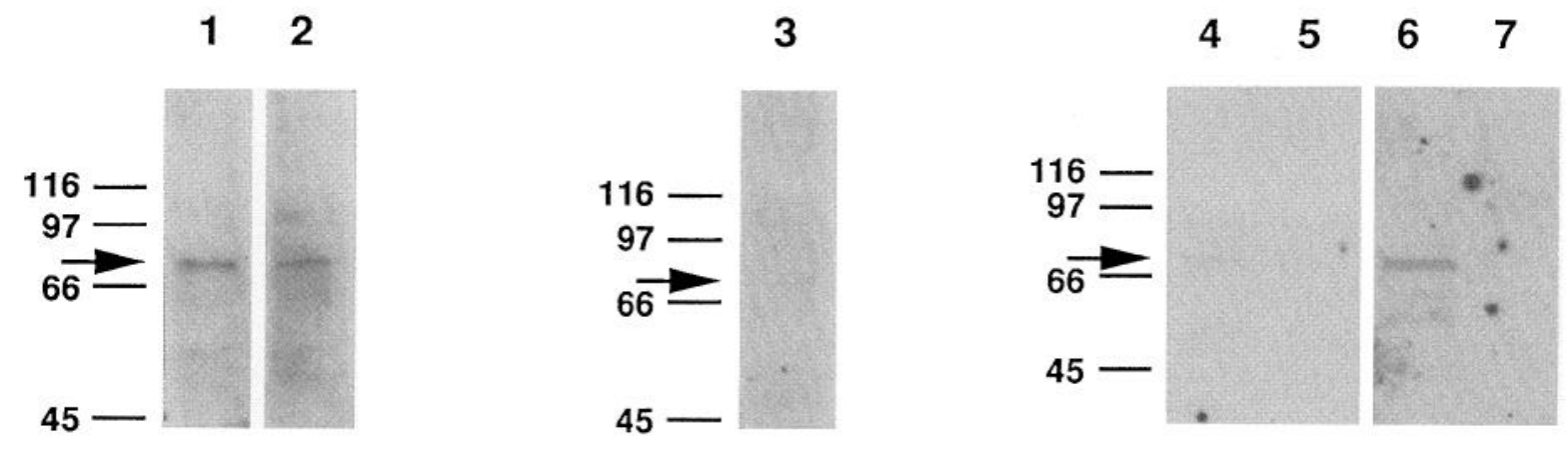

Figure 1. Western blot characterization of anti-CNTFR $\alpha$ antisera $3 \mathrm{X}$ and $1 \mathrm{Y}$. The $3 \mathrm{X}$ antiserum recognizes an $\sim 78 \mathrm{kDa}$ protein, equivalent to the estimated size of CNTFR $\alpha$, in adult brain, e.g., neocortex (lane 1) and hippocampus (lane 2) and PC12 cells (lane 6), all of which express CNTFR $\alpha$ mRNA, but not $\mathrm{C} 6$ cells (lane 7), which lack CNTFR $\alpha$ mRNA. The $1 \mathrm{Y}$ antiserum is significantly less effective but similarly detects an $\sim 78 \mathrm{kDa}$ protein in adult brain, e.g., neocortex (lane 3) and PC12 cells (lane 4), but not C6 cells (lane 5). Both antisera also recognize a minor, smaller species in PC12 cells that may represent a degraded form of $\operatorname{CNTFR} \alpha$.

incubation of the antisera with their corresponding antigen peptides (i.e., overnight at $4^{\circ} \mathrm{C}$ with $30 \mu \mathrm{M}$ peptide) specifically blocked antisera labeling, whereas preincubation with equal concentrations of nonantigen peptides did not block labeling (Figs. $2 A-D, 4 D, E, 5 C-F$ ) (note double-dissociation of peptide-blocking activities demonstrated in Fig. 2A-D).

\section{CNTFR $\alpha$ expression in the adult brain}

The $3 \mathrm{X}$ and $1 \mathrm{Y}$ antisera were used to map immunohistochemically the expression of $\mathrm{CNTFR} \alpha$ in the adult brain. Labeling appeared to be confined to cells of neuronal morphology and absent from all glial cells with most, and possibly all, neurons displaying at least low levels of immunoreactivity. However, the labeling reliably was most intense in several distinct classes of neurons (Table 1). In the neocortex, the perikarya and dendrites of layer five pyramidal neurons displayed elevated levels of CNTFR $\alpha$ immunoreactivity (Fig. $2 G, H$ ). A similar level of immunoreactivity was detected in the granule cells of the dentate gyrus and the perikarya and apical dendrites of hippocampal pyramidal cells and neurons in the subiculum (Fig. $2 F$ ). The perikarya and dendrites of neurons in the piriform cortex and the perikarya as well as principal and accessory dendrites of olfactory bulb mitral cells also were densely immunoreactive as was neuropil occupying the entire olfactory bulb external plexiform layer (Fig. $2 I$ ). In addition, elevated levels of $\mathrm{CNTFR} \alpha$ immunoreactivity were detected in the perikarya and dendrites of cerebellar Purkinje cells (Fig. 2A-D), pontine reticular neurons, gigantocellular reticular neurons (Fig. $3 A, B$ ), and neurons of the paraventricular hypothalamic nucleus, anterior thalamic nuclei, and red nucleus (Fig. 2E). Finally, several cranial nerve nuclei were densely immunoreactive. Specifically, the oculomotor, trochlear, mesencephalic and motor trigeminal, abducens, facial, vestibular complex, ambiguus, dorsal efferent of vagus, and hypoglossal nuclei contained high levels of CNTFR $\alpha$ immunoreactivity (Figs. $2 E, 3 B-F$ ). This labeling was located in the neuronal perikarya, dendrites and, in many cases, associated neuropil and identified exiting nerve roots. In notable contrast, the nucleus solitarious and the cochlear, principal sensory, and spinal trigeminal nuclei displayed, at most, low levels of CNTFR $\alpha$ immunoreactivity.

\section{CNTFR $\alpha$ expression in the adult spinal cord, dorsal root ganglion, peripheral nerve, and muscle}

$\mathrm{CNTFR} \alpha$ immunohistochemistry revealed scattered neurons throughout the gray matter of the adult spinal cord that were moderately immunoreactive and ventral horn motor neuron soma and dendrites that were densely labeled (Fig. $4 A, B$ ). In addition, high levels of immunoreactivity were detected in neuropil and emanating fibers of the intermediolateral column, axons emanating from ventral horn motor neurons, neuropil surrounding these neurons, and the ascending and descending tracts of the spinal cord (Fig. 4A,B).

CNTFR $\alpha$ immunoreactivity also was detected in the perikarya and axons of apparently all dorsal root ganglion (DRG) neurons (Fig. $4 F$ ). However, the intensity of the labeling varied greatly among individual neurons such that weakly or moderately labeled perikarya frequently were found adjacent to very intensely labeled perikarya. The axons of peripheral (sciatic) nerve also were CNTFR $\alpha$-immunoreactive (Fig. $4 D, E$ ), as might be expected given the immunoreactivity detected in axons of DRG neurons and ventral horn motor neurons. CNTFR $\alpha$ immunoreactivity was not detected in glial cells of the spinal cord and DRG or Schwann cells of the sciatic nerve. Finally, muscle (soleus) fibers were moderately to weakly immunoreactive (Fig. 4C).

\section{CNTFR $\alpha$ expression in the embryonic nervous system}

Immunohistochemical analysis of E13, E14, E16, and E18 rat embryos revealed substantial CNTFR $\alpha$ expression in the embryonic nervous system. Throughout the developmental period examined, $\operatorname{CNTFR} \alpha$ immunoreactivity was found at the highest levels in the soma and processes of differentiating neurons. These included neurons in the DRG, ventral horn and intermediolateral column of the spinal cord, sympathetic ganglia, and developing brainstem nuclei (Figs. 5, 6). Low levels of labeling also were observed in neuronal precursor cells bordering the ventricles of the brain and spinal cord (Figs. 5, 6). No CNTFR $\alpha$ immunoreactivity was detected in peripheral organs.

\section{DISCUSSION}

In the work described here, two anti-CNTFR $\alpha$ antisera were raised, affinity-purified, characterized, and used as probes in the immunohistochemical mapping of $\operatorname{CNTFR} \alpha$ expression in the adult and embryonic nervous systems. The specificity of the antibodies was verified by several critical results. First, both antisera recognized specifically a protein species in Western blot experiments that migrates at a rate equivalent to that of CNTFR $\alpha$. Second, the antisera detected this protein species in brain and $\mathrm{PC} 12$ cells, which express CNTFR $\alpha$ mRNA, but not in C6 cells, which lack CNTFR $\alpha$ mRNA. Third, the antisera, although raised against completely independent CNTFR $\alpha$ peptides, both produced the same patterns of immunohistochemical labeling. Finally, the immunohistochemical labeling by 


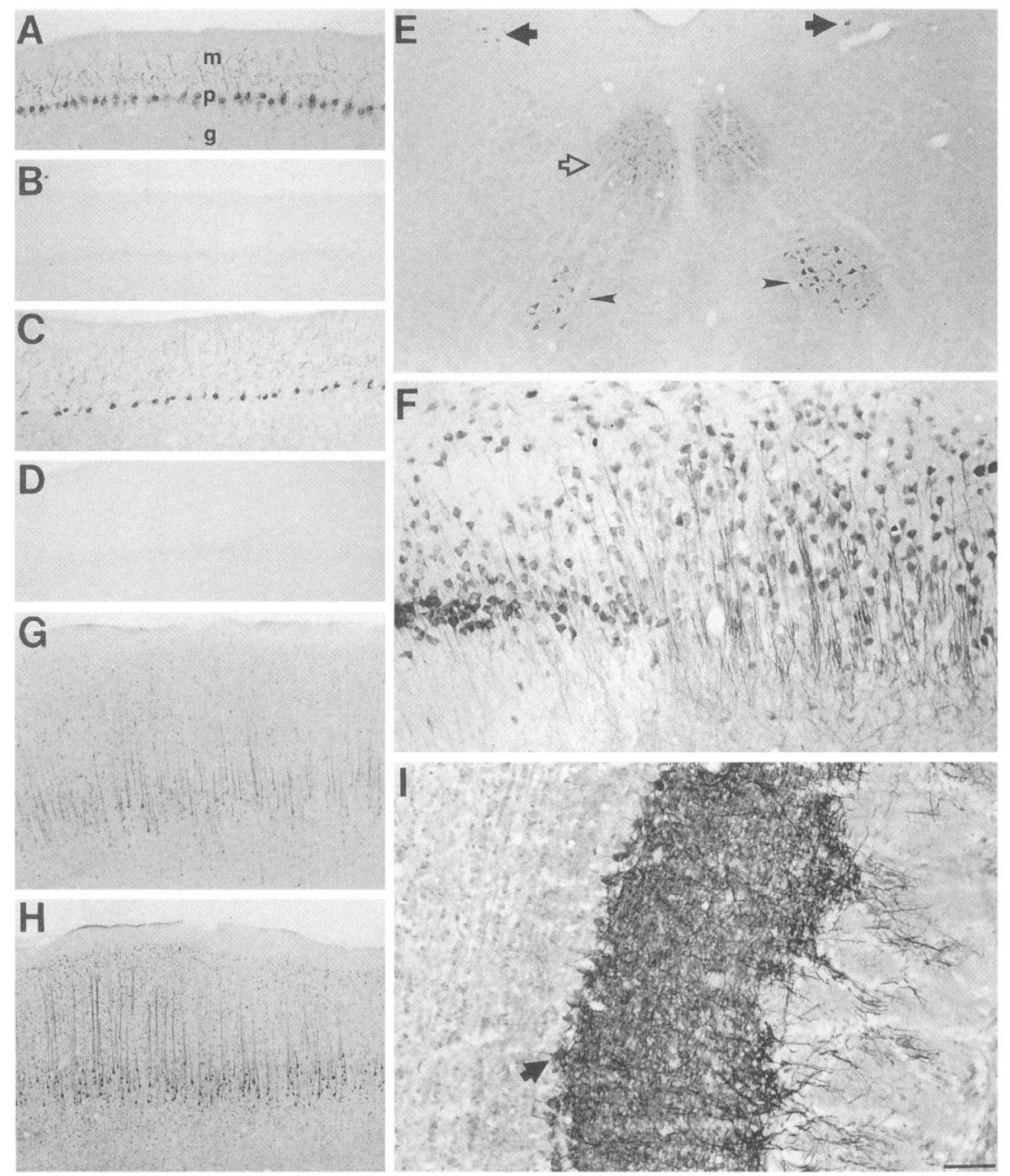

Figure 2. Immunohistochemical localization of CNTFR $\alpha$ in adult rat brain. $A-D$, Cerebellar cortex molecular $(m)$, Purkinje cell $(p)$, and granular $(g)$ layers probed with either anti-CNTFR $\alpha$ antiserum 1Y $(A, B)$ or anti-CNTFR $\alpha$ antiserum $3 \mathrm{X}(C, D)$ that was preincubated with CNTFR $\alpha$ peptide $1(B$, $C$ ) or CNTFR $\alpha$ peptide $3(A, D)$. E, Mesencephalic trigeminal nuclei (solid arrows), oculomotor nuclei (open arrow), and red nuclei (arrowheads) labeled with antiserum 1Y.F, CA1-subiculum (left and right, respectively) transitional region probed with antiserum $3 \mathrm{X}$. $G, H$, Neocortex probed with antiserum $1 \mathrm{Y}(G)$ or antiserum $3 \mathrm{X}(H)$. I, Olfactory bulb mitral cells (e.g., arrow) and external plexiform layer labeled with antiserum $3 \mathrm{X}$. All sections are coronal. Scale bar: $A-D, 120 \mu \mathrm{m} ; E, G, H, 240 \mu \mathrm{m} ; F, I, 60 \mu \mathrm{m}$. 

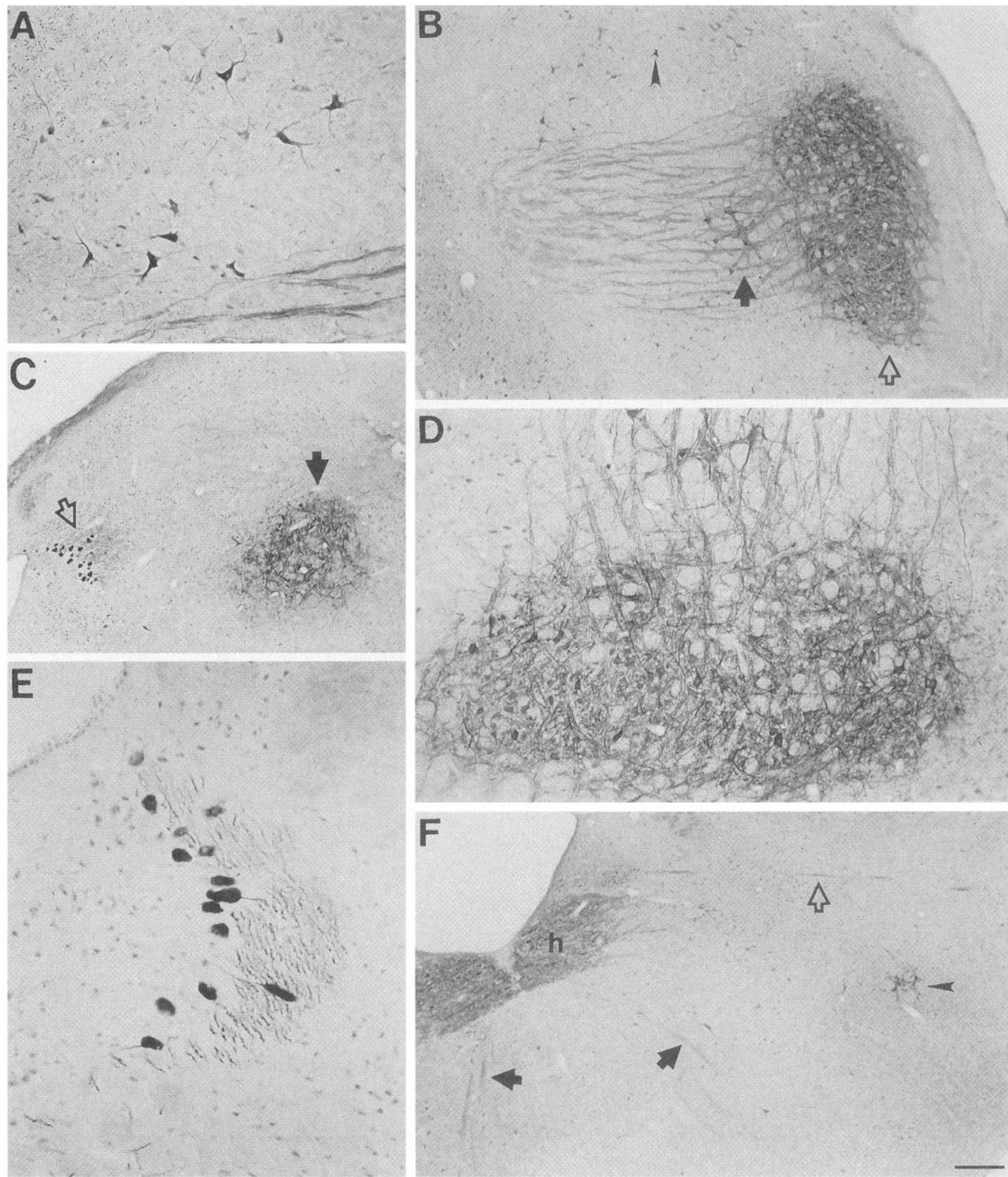

Figure 3. Immunohistochemical localization of CNTFR $\alpha$ in adult rat brainstem. $A$, Gigantocellular reticular neurons and ascending facial nucleus fibers. $B$, Gigantocellular reticular neurons (c.g., arrowhead), facial nucleus (open arrow), accessory facial nucleus (solid arrow), and ascending fibers. $C$, Motor trigeminal nucleus (solid arrow) and mesencephalic trigeminal nucleus and tract (open arrow). $D$, Higher magnification of $B$. E, Mesencephalic trigeminal nucleus and tract. $F$, Hypoglossal nuclei (e.g., $h$ ) and their exiting fibers (solid arrows), nucleus ambiguus (arrowhead), and exiting fibers of the dorsal efferent nucleus of vagus (open arrow). All sections were probed with anti-CNTFR $\alpha$ antiserum $3 X$. Scale bar: $A, D, 120 \mu \mathrm{m} ; B, C, F, 240 \mu \mathrm{m} ; E, 60 \mu \mathrm{m}$. 

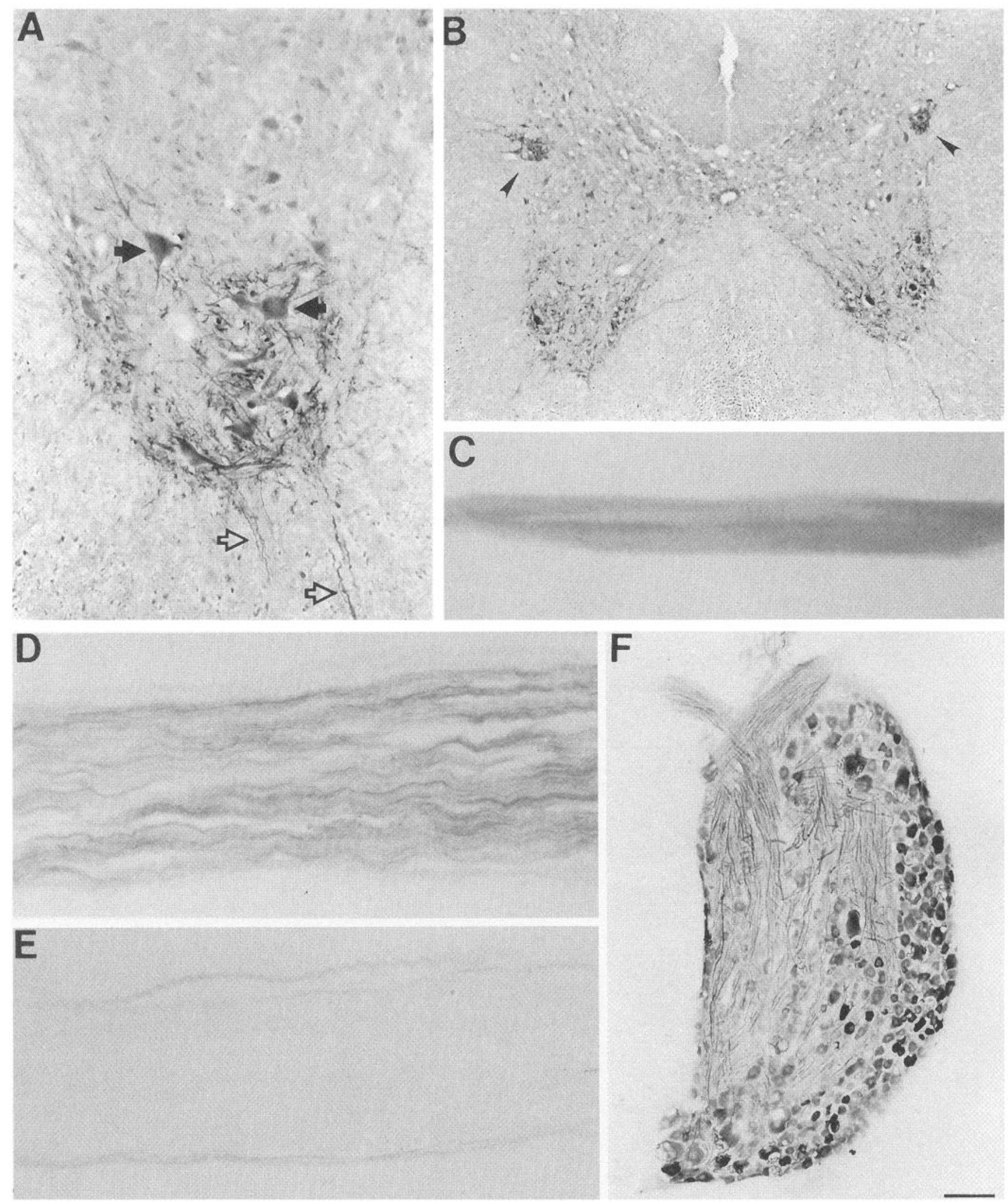

Figure 4. Immunohistochemical localization of adult CNTFR $\alpha$ expression outside the brain. $A$, Ventral horn motor neuron soma (e.g., solid arrows) and their axons (open arrows) in a transverse spinal cord section. $B$, Transverse section of spinal cord with intermediolateral columns indicated by arrowheads. $C$, Soleus muscle fibers. $D, E$, Longitudinal sections of adult peripheral (sciatic) nerve probed with antiserum $3 \mathrm{X}$ that was preincubated with either peptide $1(D)$ or peptide $3(E)$ (i.e., the antigen). $F$, DRG. All sections were probed with antiserum $3 \mathrm{X}$. Scale bar: $A, C, 60 \mu \mathrm{m} ; B, F, 120 \mu \mathrm{m} ; D, E, 240 \mu \mathrm{m}$. 

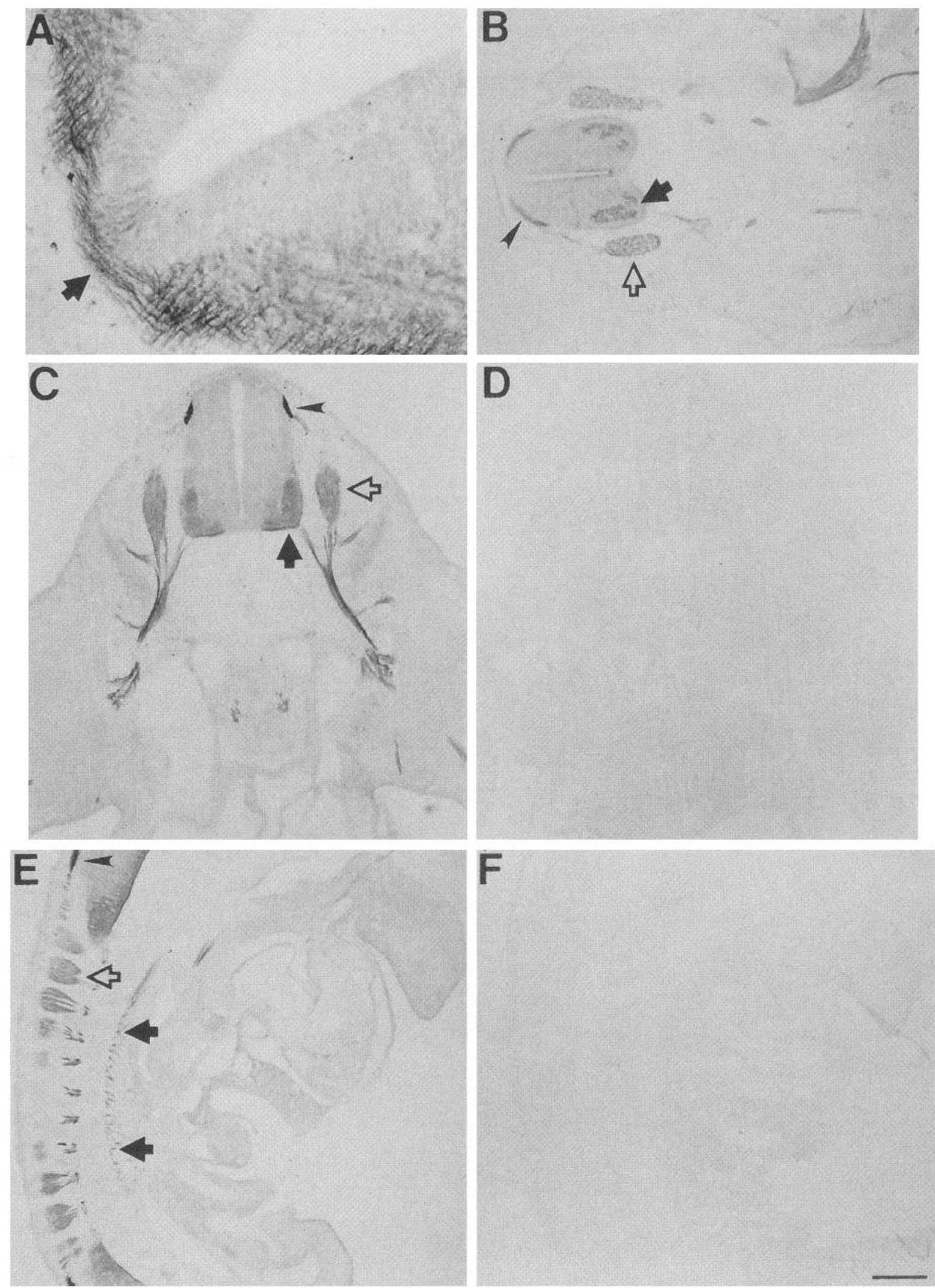

Figure 5. Embryonic CNTFR $\alpha$ expression. A, Oblique section with E13 pontine neuroepithelium as well as differentiating pontine neurons and their fibers including commissural fibers (solid arrow) probed with antiserum 3X. B. Transverse section with E16 ventral horn spinal cord motor neurons (solid arrow), dorsal root entry zones (arrowhead), DRGs (open arrow), and spinal nerve fibers probed with antiserum 3X. $C, D$, Transverse sections of E14 rat embryos probed with antiserum $3 \mathrm{X}$ that was preincubated with either peptide $2(C)$ or peptide $3(D)$ (i.e., the antigen); symbols designate same structures as in $B$. $E, F$, Sagittal sections of E14 rat embryos probed with antiserum $3 X$ that was preincubated with either peptide $2(E)$ or peptide $3(F)$ (i.e., the antigen); the arrowhead and open arrow designate the same structures as in $B$; the solid arrows designate fibers associated with sympathetic ganglia. Scale bar: $A, 60 \mu \mathrm{m} ; B, E, F, 480 \mu \mathrm{m} ; C, D, 240 \mu \mathrm{m}$. 

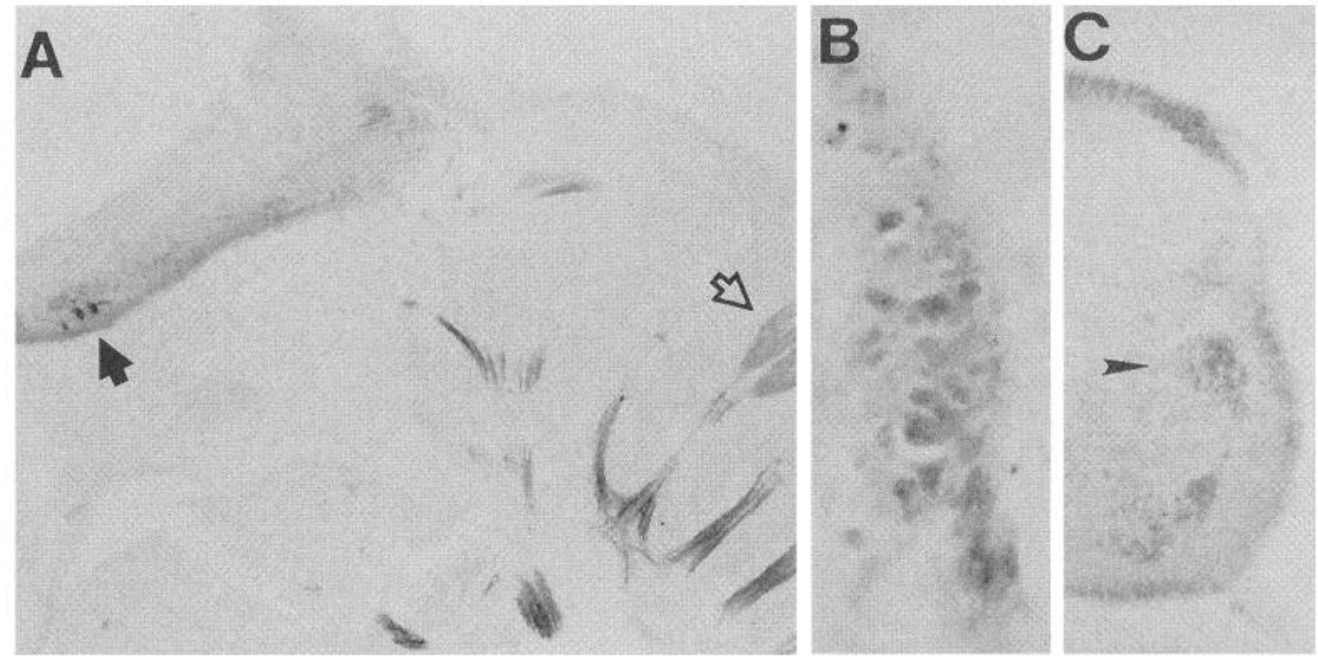

Figure 6. Embryonic CNTFR $\alpha$ expression. $A, \mathrm{E} 14$ rat nervous system including DRG (open arrow) and developing brainstem nuclei (solid arrow) in a sagittal section. $B$, E16 sympathetic ganglion neurons. $C$, Transverse section of E16 spinal cord with intermediolateral column neurons indicated by an arrowhead (ventral surface at bottom). D, Transverse section of E18 spinal cord with ventral horn motor neurons (solid arrow) and DRG (open arrow). E, Oblique section of E18 brainstem with facial nucleus (solid arrow). All sections were probed with antiserum $3 \mathrm{X}$. Scale bar: $A, E, 240 \mu \mathrm{m} ; B, 30 \mu \mathrm{m} ; C, 60$ $\mu \mathrm{m} ; D, 120 \mu \mathrm{m}$.
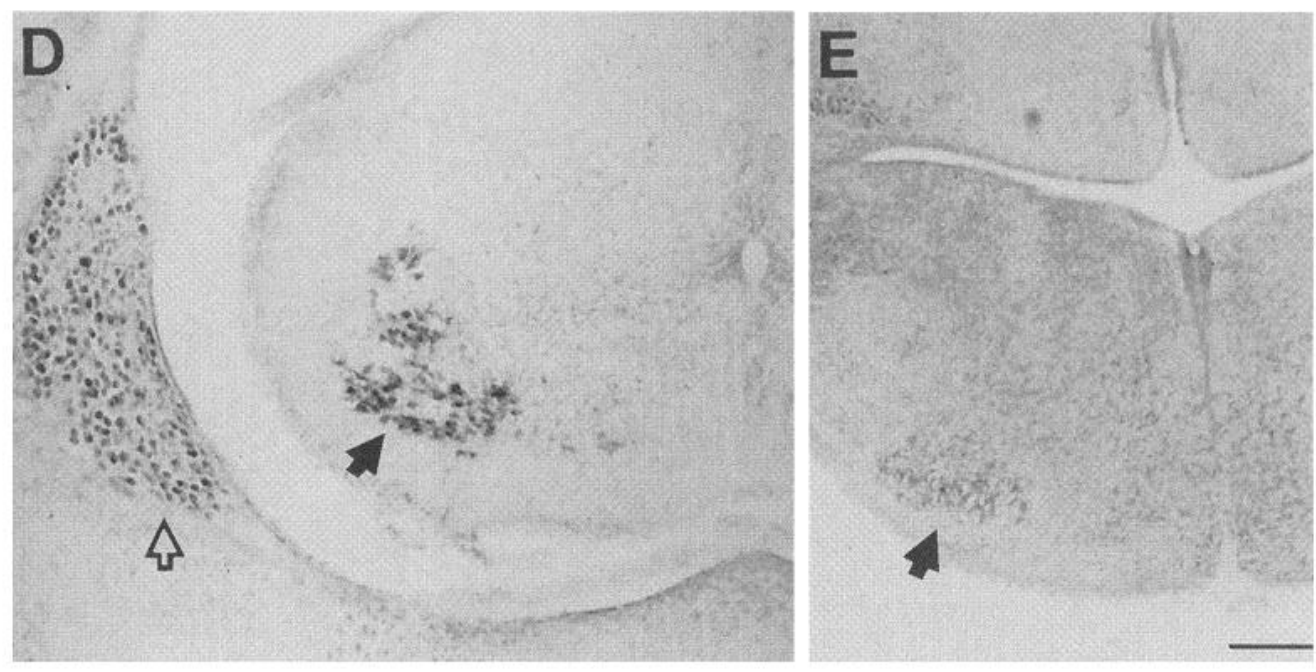

the antisera was blocked specifically by preincubation of each antiserum with antigen peptide.

The development of antisera that recognize CNTFR $\alpha$ in tissue sections made it possible to determine the in situ expression pattern of CNTFR $\alpha$ protein. Moreover, the immunohistochemical techniques enabled us to map sites of CNTFR $\alpha$ expression and, therefore, potential sites of CNTFR $\alpha$ in vivo function at a subcellular level of resolution.

Our results generally are consistent with the one reported anatomical study of CNTFR $\alpha$ mRNA expression (Ip et al., 1993). For instance, this in situ hybridization study found at least low levels of CNTFR $\alpha$ mRNA throughout the brain in neurons but not glia. Regions displaying prominent CNTFR $\alpha$ mRNA labeling included ventral horn motor neurons, the hippocampal pyramidal cell layer, the dentate gyrus granule cells, the subiculum, layer five of the neocortex, and the facial nucleus. A few regions, such as the substantia nigra pars reticulata, displayed prominent CNTFR $\alpha$ mRNA labeling but only moderate to low CNTFR $\alpha$ immunoreactivity in the present study. These discrepancies may result from regional variations in CNTFR $\alpha$ mRNA translation or CNTFR $\alpha$ stability. It also is possible that the discrepancies reflect the movement of CNTFR $\alpha$ from CNTFR $\alpha$-synthesizing cells to cells that do not synthesize $\operatorname{CNTFR} \alpha$. Thus, recent studies have suggested that CNTFR $\alpha$ is released from cells in vivo after digestion of its glycosyl-phosphatidylinositol linkage to the cellular membrane and subsequently forms functional CNTF receptors by interacting with the LIFR $\beta$ and gp130 of cells that do not express CNTFR $\alpha$ (Davis et al., 1993a).

The in situ hybridization study also detected relatively high levels of CNTFR $\alpha$ mRNA in embryonic, neuronal precursors. In contrast, we detected only low levels of CNTFR $\alpha$ immunoreactivity in these cells. Although this difference also may result from variations in CNTFR $\alpha$ mRNA translation or CNTFR $\alpha$ stability, it also is possible that it reflects a temporal difference in the expression of CNTFR $\alpha$ mRNA compared to CNTFR $\alpha$ protein. Thus, before their differentiation, neuronal precursors may begin to express higher levels of CNTFR $\alpha$ mRNA that are not completely translated into $\mathrm{CNTFR} \alpha$ protein and processed until the cells have begun to migrate and differentiate.

It is noteworthy that many of the cell types containing the highest levels of CNTFR $\alpha$ immunoreactivity in the adult nervous system participate in motor functions. Thus, the ventral horn motor neurons, neocortical pyramidal cells, cerebellar Purkinje cells, pontine reticular neurons, gigantocellular reticular neurons, and neurons of the red nucleus and motor cranial nerve nuclei are intimately involved in motor control. These data, in combination with previous studies of the effects of CNTF on motor neurons (Sendtner et al., 1990, 1992; Oppenheim et al., 1991; Mitsumoto et al., 1994b), suggest that CNTFR $\alpha$ signal transduction plays an in vivo maintenance role for several classes of motor system neurons. The data also reveal many potential sites of therapeutic action for exogenously administered CNTF, which has been 
Table 1. Summary of cell types expressing elevated levels of CNTFR $\alpha$ immunoreactivity
Location

Adult brain

Olfactory bulb mitral cells

Neocortical layer 5 pyramidal cells

Hippocampal formation

Pyramidal cells

Granule cells

Subiculum neurons

Piriform cortex pyramidal cells

Paraventricular hypothalamic nucleus

Anterior thalamic nuclei

Red nucleus

Pontine reticular neurons

Gigantocellular reticular neurons

Cerebellar Purkinje cells

Cranial nerve nuclei

Oculomotor

Trochlear

Mesencephalic

Motor trigeminal

Abducens

Facial

Vestibular complex

Ambiguus

Dorsal efferent of vagus

Hypoglossal

Adult spinal cord

Ventral horn motor neurons

A subset of other neurons

Intermediolateral neurons

(Soma)

(Surrounding neuropil)

Adult dorsal root ganglion neurons

Adult muscle (soleus)

Embryonic nervous system (E13 to

E18)

Differentiating brain neurons

(Soma)

(Processes)

Ventral horn neurons

Intermediolateral neurons

Dorsal root ganglia neurons

Sympathetic ganglia neurons
Relative labeling ${ }^{a}$

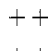

$++$

$++$

$+$

$++$

$+$

$+$

$+$

$++$

$+$

$+$

$+$

$+$

$+$

$++$

$++$

$+$

$++$

$++$

$++$

$+$

$+$

$++$

$+$

$+$

$++$

low to ++

low to + $\overline{a+\text {, Significantly elevated labeling compared with !ow levels present in apparently all }}$ neurons; ++ , intensely labeled.

shown to reduce behavioral symptoms in genetic mouse models of motor diseases (Sendtner et al., 1992; Mitsumoto et al., 1994a,b) and is hoped to serve eventually as at least a component of pharmacological therapies for human motor diseases (Hefti, 1994; Lindsay et al., 1994; Sendtner et al., 1994).

The dense CNTFR $\alpha$ immunoreactivity in neurons of the mesencephalic trigcminal nuclci, vcstibular complcx nuclei, olfactory bulb, and DRG suggests that CNTFR $\alpha$ signal transduction is involved in this subset of sensory systems. This pattern of CNTFR $\alpha$ expression, in conjunction with the effects of CNTF on sensory neurons (Mey and Thanos, 1993; Richardson, 1994), also supports the possibility that exogenously administered CNTF may attenuate or arrest disease-induced loss of these sensory neurons.

CNTTR $\alpha$ immunoreactivity also was detected outside of sensory and motor systems. The widespread, low-level CNTFR $\alpha$ immunoreactivity found in many classes of neurons implies that a wide variety of neurons in some way depends on CNTFR $\alpha$. The intense CNTFR $\alpha$ immunoreactivity associated with neurons in the hippocampal formation suggests that $\mathrm{CNTFR} \alpha$ contributes to normal hippocampal function. The role of CNTFR $\alpha$ in the hippocampus may involve neuronal maintenance, as suggested by in vitro studies (Ip et al., 1991) and the recent in vivo demonstration that exogenous CNTF administration reduces ischemia-induced loss of hippocampal neurons (Wen et al., 1995).

The present localization of CNTFR $\alpha$ to peripheral nerve axons clearly is consistent with the demonstration that CNTF can be transported retrogradely by these axons (Curtis et al., 1993). In addition to any such participation in target-derived trophic support mechanisms, the axonal CNTFR $\alpha$ also may be available immediately to interact with any Schwann cell CNTF released by peripheral nerve lesion. The CNTFR $\alpha$ thereby may contribute to peripheral nerve regeneration responses as previously proposed (Thoenen, 1991).

In many of the neurons displaying dense CNTFR $x$ immunoreactivity, much of the immunoreactivity was localized to dendritic regions that frequently were significant distances from the cell soma. In addition, most of the immunoreactive cranial nerve neurons as well as the ventral horn motor neurons were surrounded with densely immunoreactive fibers and neuropil. This subcellular distribution of CNTFR $\alpha$ appears to be incompatible with a view of CNTFR $\alpha$ as a neurotrophic factor receptor involved exclusively in survival-promoting signal transduction initiated by retrograde axonal transport of target- or lesion-derived growth factors. However, recent studies indicate that neurotrophic factors can serve a wide range of functions in addition to their target-derived, survival-promoting actions (Korsching, 1993; Snider, 1994; Acheson et al., 1995). For example, CNTF has heen shown to regulate neurotransmitter release acutely by acting (presumably on CNTFR $\alpha$ ) at the cell body level (Stoop and Poo, 1995). Therefore, the dendritic CNTFR $\alpha$ presently identified may participate in a variety of somatic signaling events involving CNTF or CNTF-like ligands.

The present examination of CNTFR $\alpha$ expression during embryonic nervous system development revealed relatively high levels of CNTFR $\alpha$ immunoreactivity in apparently all differentiating neurons and many of their axons. As noted above, genetic "knock-out" studies indicate that CNTFR $\alpha$ plays an essential role(s) during embryogenesis but is unlikely to be activated by CNTF during this period. Presumably, other endogenous ligands similar to CNTF initiate embryonic CNTFR $\alpha$ signal transduction. Such ligands may be related to, or may be species homologs of, chicken growth-promoting activity (Eckenstein et al., 1990), which is structurally similar to CNTF, expressed embryonically, released in active form, and displays similar, but not identical, receptor-binding characteristics to those of CNTF (Leung et al., 1992; Heller et al., 1993). The pattern of embryonic CNTFR $\alpha$ expression described here and results from previous in vitro and in vivo studies of the effects of CNTF on embryonic neurons (Richardson, 1994) combine to suggest that CNTFR $\alpha$ regulates embryonic neuronal survival and differentiation, including target innervation. 


\section{REFERENCES}

Acheson A, Conover JC, Fandl JP, DiChiara TM, Russell M, Thadani A, Squinto SP, Yancopoulos GD, Lindsay RM (1995) A BDNF autocrine loop in adult sensory neurons prevents cell death. Nature 374:450-453.

Baumann H, Ziegler SF, Mosley B, Morella KK, Pajovic S, Gearing DP (1993) Reconstitution of the response to leukemia-inhibiting factor, oncostatin $\mathrm{M}$, and ciliary neurotrophic factor in hepatoma cells. J Biol Chem 268:8414-8417.

Blottner D, Bruggemann W, Unsicker K (1989), Ciliary neurotropic factor supports target-deprived preganglionic sympathetic spinal cord neurons. Neurosci Lett 105:316-320.

Bonni A, Frank DA, Schindler C, Greenberg ME (1993) Characterization of a pathway for ciliary neurotrophic factor signaling to the nucleus. Science 262:1575-1579.

Boulton TG, Stahl N, Yancopoulos GD (1994) Ciliary neurotrophic factor/leukemia-inhibitory factor/interleukin-6/oncostatin $M$ family of cytokines induces tyrosine phosphorylation of a common set of proteins overlapping those induced by other cytokines and growth factors. J Biol Chem 269:11648-11655.

Clatterbuck RE, Price DL, Koliatsos VE (1993) Ciliary neurotrophic factor prevents retrograde neuronal death in the adult central nervous system. Proc Natl Acad Sci USA 90:2222-2226.

Clatterbuck RE, Price DL, Koliatsos VE (1994) Further characterization of the effects of brain-derived neurotrophic factor and ciliary neurotrophic factor on axotomized neonatal and adult mammalian motor neurons. J Comp Neurol 342:45-56.

Curtis R, Adryan KM, Zhu Y, Harkness PJ, Lindsay RM, DiStefano PS (1993) Retrograde axonal transport of ciliary neurotrophic factor is increased by peripheral nerve injury. Nature 365:253-255.

Davis S, Aldrich TH, Ip NY, Stahl N, Scherer S, Farruggella T, DiStefano PS, Curtis R, Panayotatos N, Gascan H, Chevalier S, Yancopoulos GD (1993a) Released form of CNTF receptor $\alpha$ component as a soluble mediator of CNTF responses. Science 259:1736-1739.

Davis S, Aldrich TH, Stahl N, Pan L, Taga T, Kishimoto T, Ip NY, Yancopoulos GD (1993b) LIFR $\beta$ and gp130 as heterodimerizing signal transducers of the tripartite CNTF receptor. Science 260:1805-1808.

Davis S, Aldrich TH, Valenzuela DM, Wong V, Furth ME, Squinto SP, Yancopoulos GD (1991) The receptor for ciliary neurotrophic factor. Science 253:59-63.

Eckenstein FP, Esch F, Holbert T, Blacher RW, Nishi R (1990) Purification and characterization of a trophic factor for embryonic peripheral neurons: comparison with fibroblast growth factors. Neuron 4:623-631.

Greene LA, Sobeih MM, Teng KK (1991) Methodologies for the culture and experimental use of the PC12 rat pheochromocytoma cell line. In: Culturing nerve cells (Banker G, Goslin K, eds), pp. 207-226. Cambridge: MIT.

Gurney ME, Yamamoto H, Kwon Y (1992) Induction of motor neuron sprouting in vivo by ciliary neurotrophic factor and basic fibroblast growth factor. J Neurosci 12:3241-3247.

Hagg T, Quon D, Higaki J, Varon S (1992) Ciliary neurotrophic factor prevents neuronal degeneration and promotes low affinity NGF receptor expression in the adult rat CNS. Neuron 8:145-158.

Hagg T, Varon S (1993) Ciliary neurotrophic factor prevents degeneration of adult rat substantia nigra dopaminergic neurons in vivo. Proc Natl Acad Sci USA 90:6315-6319.

Hefti F (1994) Neurotrophic factor therapy for nervous system degenerative diseases. J Neurobiol 25:1418-1435.

Helgren ME, Friedman B, Kennedy M, Mullolland K, Messer A, Wong V, Lindsay RM (1992) Ciliary neurotrophic factor delays motor impairments in the Mnd mouse, a genetic model of motor neuron disease. Soc Neurosci Abstr 18:618.

Heller S, Huber J, Finn TP, Nishi R, Rohrer H (1993) GPA and CNTF produce similar effects in sympathetic neurones but differ in receptor binding. NeuroReport 5:357-360.

Huber J, Dittrich F, Phelan P (1993) Characterisation of high- affinity and low-affinity receptors for ciliary neurotrophic factor. Eur J Biochem 218:1031-1039.

Ip NY, Li Y, van de Stadt I, Panayotatos N, Alderson RF, Lindsay RM (1991) Ciliary neurotrophic factor enhances neuronal survival in embryonic rat hippocampal cultures. J Neurosci 11:3124-3134.

Ip NY, McClain J, Barrezueta NX, Aldrich TH, Pan L, Li Y, Wiegand SJ, Friedman B, Davis S, Yancopoulos GD (1993) The $\alpha$ component of the CNTF receptor is required for signaling and defines potential CNTF targets in the adult and during development. Neuron 10:89-102.

Ip NY, Nye SH, Boulton TG, Davis S, Taga T, Li Y, Birren SJ, Yasukawa K, Kishimoto T, Anderson DJ, Stahl N, Yancopoulos GD (1992) CNTF and LIF act on neuronal cells via shared signalling pathways that involve the IL-6 signal transducing receptor component gp130. Cell 69:1121-1132.

Ip NY, Yancopoulos GD (1992) Ciliary neurotrophic factor and its receptor complex. Prog Growth Factor Res 4:139-155.

Kirsch M, Hofmann H-D (1994) Expression of ciliary neurotrophic factor receptor mRNA and protein in the early postnatal and adult rat nervous system. Neurosci Lett 180:163-166.

Korsching S (1993) The neurotrophic factor concept: a re-examination. J Neurosci 13:2739-2748.

Leung DW, Parent AS, Cachianes G, Esch F, Coulombe JN, Nikolics K, Eckenstein FP, Nishi R (1992) Cloning, expression during development, and evidence for release of a trophic factor for ciliary ganglion neurons. Neuron 8:1045-1053.

Lindsay RM, Wiegand SJ, Altar CA, DiStefano PS (1994) Neurotrophic factors: from molecule to man. Trends Neurosci 17:182-190.

MacLennan AJ, Gaskin AA, Lado DC (1994) CNTFR receptor $\alpha$ mRNA expression in rodent cell lines and developing rat. Mol Brain Res 25:251-256.

Masu Y, Wolf E, Holtmann B, Sendtner M, Brem G, Thoenen H (1993) Disruption of the CNTF gene results in motor neuron degeneration. Nature 365:27 32 .

Mey J, Thanos S (1993) Intravitreal injections of neurotrophic factors support the survival of axotomized retinal ganglion cells in adult rats in vivo. Brain Res 602:304-317.

Mitsumoto H, Ikeda K, Holmlund T, Greene T, Cedarbaum JM, Wong V, Lindsay RM (1994a) The effects of ciliary neurotrophic factor on motor dysfunction in wobbler mouse motor neuron disease. Ann Neurol 36:142-148.

Mitsumoto H, Ikeda K, Klinkosz B, Cedarbaum JM, Wong V, Lindsay RM (1994b) Arrest of motor neuron disease in wobbler mice cotreated with CNTF and BDNF. Science 265:1107-1110.

Oppenheim RW, Prevette D, Qin-Wei Y, Collins F, MacDonald J (1991) Control of embryonic motoneuron survival in vivo by ciliary neurotrophic factor. Science 251:1616-1618.

Richardson PM (1994) Ciliary neurotrophic factor: a revicw. J Pharmacol Exp Ther 63:187-198.

Sahenk Z, Seharaseyon J, Mendell JR (1994) CNTF potentiates peripheral nerve regeneration. Brain Res 655:246-250.

Sendtner M, Carroll P, Holtmann B, Hughes RA, Thoenen H (1994) Ciliary neurotrophic factor. J Neurobiol 25:1436-1453.

Sendtner M, Kreutzberg GW, Thoenen H (1990) Ciliary neurotrophic factor prevents the degeneration of motor neurons after axotomy. Nature 345:440-441.

Sendtner M, Schmalbruch $\mathbf{H}$, Stockli KA, Carroll P, Kreutzberg GW, Thoenen $H$ (1992) Ciliary neurotrophic factor prevents degeneration of motor neurons in mouse mutant progressive motor neuronopathy. Nature 345:440-441.

Snider WD (1994) Functions of the neurotrophins during nervous system development: what the knockouts are teaching us. Cell 77:627-638.

Stahl N, Davis S, Wong V, Taga T, Kishimoto T, Ip NY, Yancopoulos GD (1993) Cross-linking identifies leukemia-inhibitory factor-binding protein as a ciliary neurotrophic factor receptor component. J Biol Chem 268:7628-7631.

Stahl N, Farruggella TJ, Boulton TG, Zhong Z, Darnell Jr JE, Yancopoulos GD (1995) Choice of STATs and other substrates specified by modular tyrosine-based motifs in cytokine receptors. Science 267:1349-1353.

Stahl N, Yancopoulos GD (1994) The tripartite CNTF receptor complex: activation and signaling involves components shared with other cytokines. J Neurobiol 25:1454-1466.

Stoop R, Poo M-M (1995) Potentiation of transmitter release by ciliary neurotrophic factor requires somatic signaling. Science 267:695-699.

Thoenen $H$ (1991) The changing scene of neurotrophic factors. Trends Neurosci 14:165-170.

Wen T-C, Matsuda S, Yoshimura H, Kawabe T, Sakanaka M (1995) Ciliary neurotrophic factor prevents ischemia-induced learning disability and neuronal loss in gerbils. Neurosci Lett 191:55-58. 